\title{
Tingkatkan Imunitas Tubuh Di Masa Adaptasi Kebiasaan Baru Dengan Diversifikasi Produk Olahan Ikan
}

\author{
Djuhria Wonggo dan Albert Royke Reo
}

\author{
Program Studi Teknologi Hasil Perikanan \\ Fakultas Perikanan dan Ilmu Kelautan, Universitas Sam Ratulangi. \\ Jl. Kampus Unsrat Bahu, Manado 95115, Sulawesi Utara, Indonesia. \\ *Penulis Korespondensi: djuhriawonggo@gmail.com \\ (Diterima 20-10-2020; Direvisi 28-12-2020; Dipublikasi 10-01-2021)
}

\begin{abstract}
The purpose of community service is to strengthen immune system during the adaptation of New Normal, through diversification of processed products to increase the amount of fish consumption and providing B2SA food in the online culinary business for PKK Jaga 6 women in Sea Village, Pineleng District, Minahasa Regency, North Sulawesi Province. The method used is counseling, training and mentoring and evaluation. To find out whether the product being offered was accepted by consumers, a hedonic test was conducted on 14 panelists. The diversified products offered are the manufacture of fish kaki naga, fish nuggets and fish Ilobulo. The hedonic test results showed that both the taste, texture, smell and appearance of the fish kaki naga products were between the likes and the most liked and also the most liked. For fish nuggets, consumer acceptance, in terms of taste, texture, smell and appearance, is between very, very fond. Meanwhile, consumer acceptance of Ilobulo fish starts from like to really like. This shows that the three products are very accepted by consumers, especially PKK Jaga 6 women in Sea Village, Pineleng District, Minahasa Regency, North Sulawesi Province.
\end{abstract}

Keywords: $\quad$ PKK mothers, diversification, consumer acceptance.

\begin{abstract}
Tujuan pengabdian pada masyarakat adalah meningkatkan imunitas tubuh di masa adaptasi kebiasaan baru, melalui diversifikasi produk olahan untuk meningkatkan jumlah konsumsi ikan dan menyediakan makanan B2SA pada bisnis kuliner online bagi kelompok Mitra. Metode yang digunakan adalah penyuluhan, pelatihan dan pendampingan serta evaluasi. Untuk mengetahui apakah produk yang ditawarkan diterima oleh konsumen, maka diadakan uji hedonic pada 14 orang panelis. Produk diversifikasi yang ditawarkan adalah pembuatan kaki naga ikan, nugget ikan dan Ilobulo ikan. Hasil uji hedonic menunjukkan bahwa baik rasa, tekstur, bau dan penampakkan untuk produk kaki naga ikan adalah antara disukai dan sangat disukai serta amat disukai. Untuk nugget ikan penerimaan konsumen baik dari segi rasa, tekstur, bau dan kenampakan antara sangat suka dan amat sangat suka. Sedangkan penerimaan konsumen terhadap ilobulo ikan mulai dari suka sampai sangat suka. Ini menunjukkan bahwa ketiga produk tersebut sangat diterima oleh konsumen terutama ibu-ibu PKK Jaga 6 di desa Sea Kecamatan Pineleng Kabupaten Minahasa Provinsi Sulawesi Utara.
\end{abstract}

Kata kunci: Ibu-ibu PKK, Diversivikasi, penerimaan konsumen.

\section{PENDAHULUAN}

Dalam menghadapi masa adaptasi kebiasaan baru akibat covid-19, banyak perubahan yang terjadi di masyarakat antara lain: masyarakat dianjurkan untuk meningkatkan imun tubuh agar tidak terserang dengan Covid-19, dan juga maraknya bisnis online tentang makanan siap saji.

Ikan mengandung protein, asam lemak tak jenuh omega 3 eicosapentaenoic acid (EPA) dan docosahexaenoic acid (DHA), vitamin dan mineral (Virtanen et al., 2007; Kadam and Prabhasankar, 2010; Soccol and Oetterer, 2003). Banyak manfaat protein pada manusia yaitu antara lain adalah sebagai antibodi. Antibodi terdapat di dalam tubuh yang berfungsi sebagai sistem pertahanan tubuh. Antibodi dapat mengenali antigen atau benda asing dan dapat menghancurkan benda asing dengan cara-cara tertentu baik bekerja sendiri maupun bekerja sama dengan komponen antibodi yang lain (Widyastuti, 2007).

Manfaat dari asam lemak omega 3 adalah sebagai anti peradangan dan anti penggumpalan darah, baik bagi sistem saraf pusat dan otak serta dapat mencegah Cardio Vascular Disease (CVD) (Duthie, $d k k .$, 1992). Dikemukakan juga bahwa asam lemak omega 3 yang paling banyak pada ikan adalah EPA dan DHA. Mengkonsumsi ikan secara teratur dapat mencegah terjadinya CVD. Menurut Innis (2000), asam lemak tak jenuh omega-3 berperan penting dalam perkembangan otak dan organ lainnya yang meliputi morfologis, biokimia dan molekuler. Menurut Diana (2013), 
Omega-3 merupakan asam lemak tak jenuh ganda yang mempunyai banyak manfaat untuk pertumbuhan dan perkembangan kecerdasan balita. Secara teori selaput myelin dibentuk oleh lemak (asam lemak EPA, DHA). Orang yang mengkonsumsi omega-3 secara teratur, memiliki risiko lebih kecil untuk mengalami depresi. EPA tampaknya paling efektif dalam memerangi depresi (Virtanen et al., 2007). Kurangnya asupan asam lemak omega-3 dalam makanan dapat menghambat perkembangan otak, kesehatan fisik dan interaksil lingkungan sangat berpengaruh dalam pembentukan perkembangan kognitif. Defisiensi omega-3 yang berkepanjangan dapat berakibat fatal. Kekurangan asam lemak omega-3 menimbulkan gangguan saraf dan penglihatan serta bisa mengganggu perkembangan sistem saraf. Akibatnya, mungkin saja terjadi gangguan pada sistem daya tahan tubuh, daya ingat, mental dan penglihatan (Innis, 2000).

Vitamin pada ikan terdapat pada minyak ikan. Minyak ikan dari laut kaya akan vitamin A, D dan E. Kekurangan akan vitamin D berdampak pada ostephotosis, kelemahan jaringan dan penurunan sistem kekebalan tubuh. (Larsen et al., 2011).

Pada umumnya organisme laut dan ikan mengandung mineral lebih banyak daripada hewan darat. Selenium dan yodium lebih banyak pada ikan dibandingkan dengan hewan darat (Larsen et al., 2011). Ikan umumnya Tuna kaya akan selenium. Kandungan selenium pada produk kerang lebih tinggi daripada ikan. Sementara ikan laut dan kerang kaya akan yodium. Oysters kaya akan yodium diikuti dengan remis, lobster, udang, udang karang dan ikan laut (Venugopahl, 2010 dalam Susanto dan Fahmi, 2012). Konsumsi selenium dapat menghambat tumbuhnya kanker. American Institute of Cancer Research (AICR) melaporkan bahwa selenium dapat mencegah kanker kulit, dan kanker paru-paru. Keberadaan selenium dalam tubuh berdampak pada penyakit jantung dan saraf (Larsen et al., 2011). Konsumsi yodium yang dianjurkan untuk orang dewasa adalah 150 $\mu \mathrm{g} /$ hari. Untuk wanita selama hamil ditambahkan sebanyak $25 \mu \mathrm{g} / \mathrm{hari}$ dan menyusui $50 \mu \mathrm{g} / \mathrm{hari}$ konsumsi yodium. Kekurangan yodium dapat menyebabkan kerusakan otak dan penurunan mental (Venugopal, 2010 dalam Susanto dan Fahmi 2012).

Diversifikasi produk adalah suatu upaya mencari dan mengembangkan produk atau pasar yang baru, atau keduanya, dalam rangka mengejar pertumbuhan, peningkatan penjualan, profitabilitas dan fleksibilitas (Tjiptono, 2007), Wahyudi (2006), diversifikasi produk merupakan kegiatan pertumbuhan produk yang dilakukan untuk melakukan hasil penjualan melalui daur produk.

Tujuan pengabdian pada masyarakat adalah meningkatkan imunitas tubuh di masa adaptasi kebiasaan baru, melalui diversifikasi produk olahan untuk meningkatkan jumlah konsumsi ikan dan menyediakan makanan B2SA pada bisnis kuliner online bagi ibu-ibu PKK Jaga 6 di desa Sea Kecamatan Pineleng Kabupaten Minahasa Provinsi Sulawesi Utara.

\section{METODOLOGI}

Pengabdian ini dilaksanakan pada tanggal 18 Juli 2020 pada kelompok Mitra. Metode yang digunakan adalah penyuluhan, pelatihan dan pendampingan serta evaluasi. Penyuluhan tentang konsumsi ikan untuk meningkatkan imun tubuh serta manfaat diversifikasi untuk penyediaan makan B2SA serta pengembangan bisnis RT melalui online. Pelatihan dan pendampingan untuk membuat produk diversifikasi olahan ikan yang meliputi: pembuatan nugget, kaki naga dan ilobulo ikan. Tahap akhir adalah untuk mengetahui penerimaan konsumen terhadap ketiga produk yang dihasilkan, maka diminta kepada ibu-ibu untuk mengisi lembar penilaian uji hedonik sesuai SNI 01-2346-2006.

Bahan dan alat yang digunakan adalah daging ikan tanpa kulit dan tulang yang dibuat pasta, tepung tapioka, bawang putih, bawang bombay, telur, tepung bumbu, garam, roti tawar, susu cair, daun seledri, wortel, kemangi, tepung roti, tongkat es krim, daun pisang, minyak goreng dan tusuk gigi. Alat yang digunakan adalah alat penggiling daging (Chopper), loyang, dandang, wajan dan kompor. Cara pembuatan produk adalah sebagai berikut: 


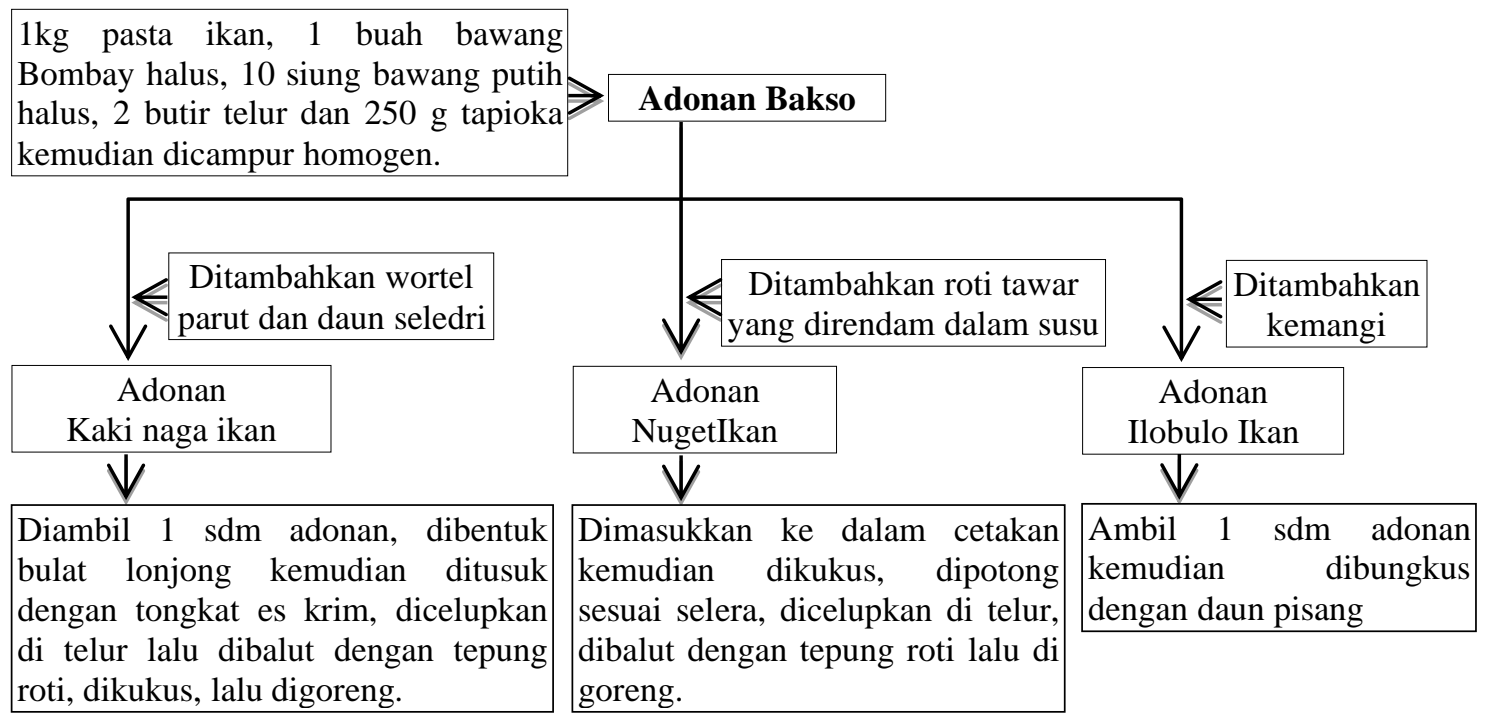

\section{HASIL DAN PEMBAHASAN}

\section{Penyuluhan}

Penyuluhan pada ibu-ibu PKK Jaga 6 di desa Sea Kecamatan Pineleng Kabupaten Minahasa Provinsi Sulawesi Utara, dihadiri oleh 5 orang ibu, karena kondisi yang tidak memungkinkanya itu masa adaptasi kebiasaan baru.

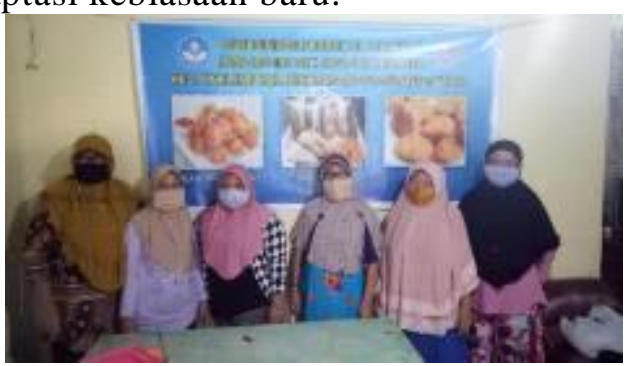

Gambar 1. Wakil PKK Peserta Penyuluhan.

\subsection{Tingkatkan Imun Tubuh dengan Konsumsi Ikan.}

Komponen gizi yang terkandung pada ikan yaitu: sebagai sumber protein dan asam amino esensial. Kandungan Protein pada ikan 18-22\%. Sumber asam lemak tak jenuh: EPA dan DHA. Sumber mineral: Fe, I, Se, Zn dan F. Sumber vitamin: A, D, B1 dan B12 (Virtanen et al., 2007). Banyak manfaat protein, salah satunya adalah untuk meningkatkan kekebalan tubuh (Widyastuti, 2007). Manfaat EPA adalah dalam sistem hormon dan kekebalan tubuh. EPA merupakan precursor hormon yang penting, seperti zat kimia yang diproduksi dalam tubuh yang disebut eikosanoid. EPA mencegah aterosklerosis yang memberikan efek positif dalam pencegahan dan pengobatan penyakit jantung aterosklerosis. DHA sangat dibutuhkan oleh wanita hamil karena mempengaruhi kerja otak dan sistem saraf, mengobati tekanan darah tinggi dan diabetes (Frey, 2020). Anjuran FAO, WHO (2013): DHA untuk anak usia 6-24 bulan adalah10-12 mg/hari dan Ibu hamil dan menyusui adalah $200 \mathrm{mg} /$ hari. Vitamin A terdapat pada minyak hati ikan bermanfaat mencegah kebutaan pada anak. Vitamin D terdapat pada daging ikan dan minyak hati ikan. Vitamin ini pertumbuhan dan kekuatan tulang. Vitamin B 6 dibutuhkan dalam metabolisme asam amino, lemak dan mencegah anemia dan kerusakan saraf. Vitamin B12 dibutuhkan dalam pembentukan sel-sel darah merah, membantu metabolisme lemak, melindungi jantung dan kerusakan saraf. Mineral Zat besi (Fe) ikan lebih mudah diserap tubuh ketimbang dari sumber lain, yang berfungsi mencegah anemia. Yodium (I) mencegah penyakit gondok. Membantu pertumbuhan dan kecerdasan anak. Selenium (Se) berfungsi sebagai antioksidan yang melindungi tubuh dari radikal bebas. Seng (Zn) berfungsi sebagai enzim dan hormon. Fluor (F) berfungsi menyehatkan gigi anak (Virtanen et al., 2007). 


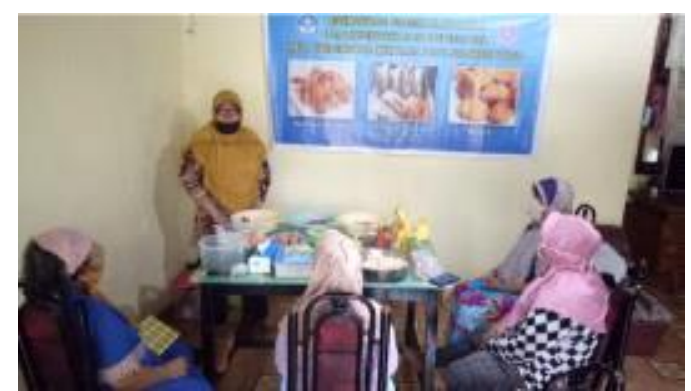

Gambar 2. Peserta mengikuti Penyuluhan.

\subsection{Manfaat Diversifikasi Produk}

Diversifikasi produk adalah suatu upaya mencari dan mengembangkan produk atau pasar yang baru atau keduanya, dalam rangka mengejar pertumbuhan, peningkatan penjualan, profitabilitas dan fleksibilitas. Diversifikasi adalah salah satu investasi yang menguntungkan bagi pengusaha karena dapat meminimalisir kerugian akibat produk tidak terjual dengan bagus (Elizabeth, 2011).

Saat ini penanganan dan pengolahan ikan perlu diusahakan secara optimal, padahal sebetulnya teknologi penanganan dan pengolahannya cukup sederhana dan tidak memerlukan modal yang besar dan peralatan yang canggih. Jika teknologi penanganan dan pengolahan ikan dapat dikembangkan dan diterapkan dengan baik, maka nilai tambah pada perekonomian masyarakat dapat tercapai. Pengembangan produk hasil perikanan bertujuan untuk memberikan alternatif pada masyarakat dalam mengkonsumsi produk perikanan yang tentunya sesuai dengan selera masyarakat, aman dan sehat.

\section{Pelatihan dan Pendampingan}

Pelatihan dan pendampingan pada ibu-ibu PKK Jaga 6 di desa Sea Kecamatan Pineleng Kabupaten Minahasa Provinsi Sulawesi Utara adalah diversifikasi produk ikan olahan berupa kaki naga ikan, nugget ikan dan ilobulo ikan. Kegiatan tersebut dapat dilihat pada gambar berikut:
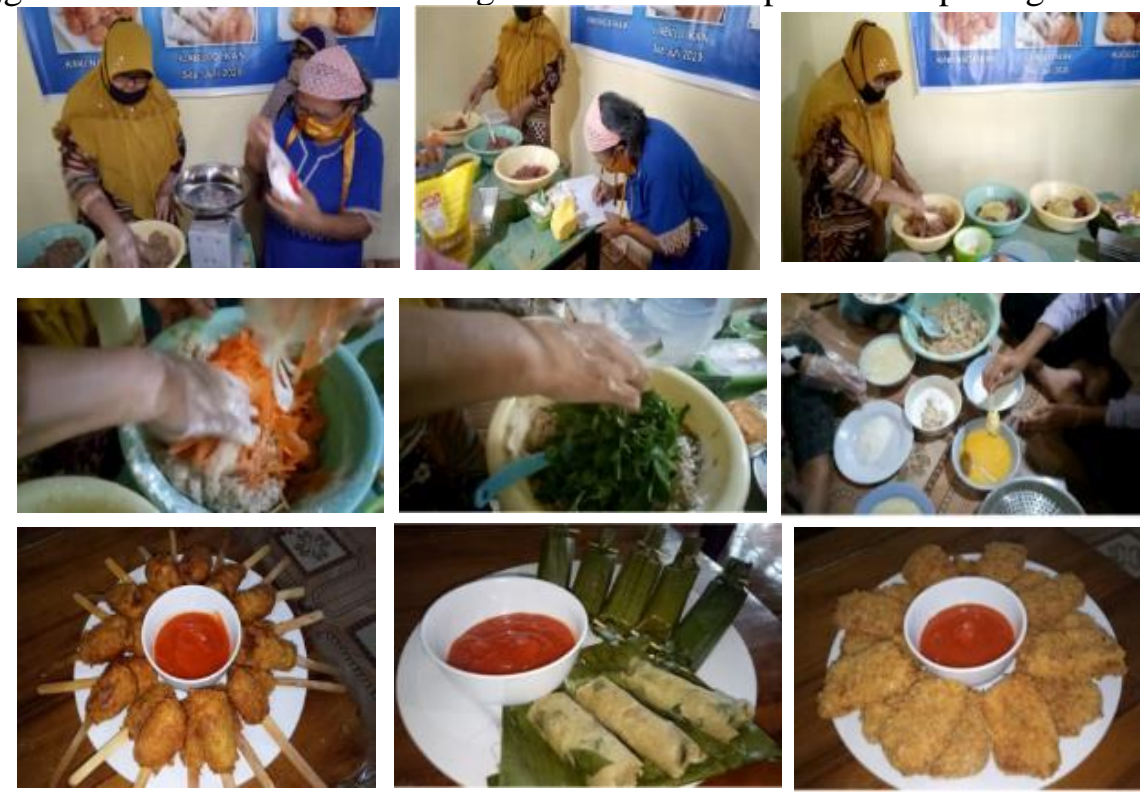

Gambar 3. Kegiatan Pelatihan dan Pendampingan Serta Produk Yang Dihasilkan.

Kegiatan pelatihan dan pendampingan pada ibu-ibu PKK Jaga 6 di desa Sea Kecamatan Pineleng Kabupaten Minahasa Provinsi Sulawesi Utara, sangat diterima oleh ibu-ibu PKK karena menurut mereka terutama untuk mengisi kejenuhan di masa adaptasi kebiasaan baru dan juga mendapatkan ilmu tentang menciptakan makanan siap saji yang bersifat B2SA dan produk ini dapat dijadikan produk bisnis kuliner rumahan yang baru. 


\section{Evaluasi.}

Produk yang dihasilkan seperti: Kaki naga, nugget dan ilobulo ikan kemudian dinilai secara organoleptik oleh 14 panelis, yaitu oleh 5 orang panelis adalah peserta penyuluhan kemudian ditambah dengan 9 orang peserta dari keluarga tetangga. Panelis mengisi lembar penilaian uji hedonik sesuai SNI 01-2346-2006, berdasarkan penerimaan panelis tentang produk kaki naga, nugget dan ilobulo ikan. Hasil penerimaan konsumen adalah sebagai berikut:

\subsection{Kaki Naga Ikan.}

Hasil uji hedonik tentang penerimaan konsumen terhadap rasa tekstur, bau dan kenampakan pada produk kaki naga ikan dapat dilihat pada Gambar 4.

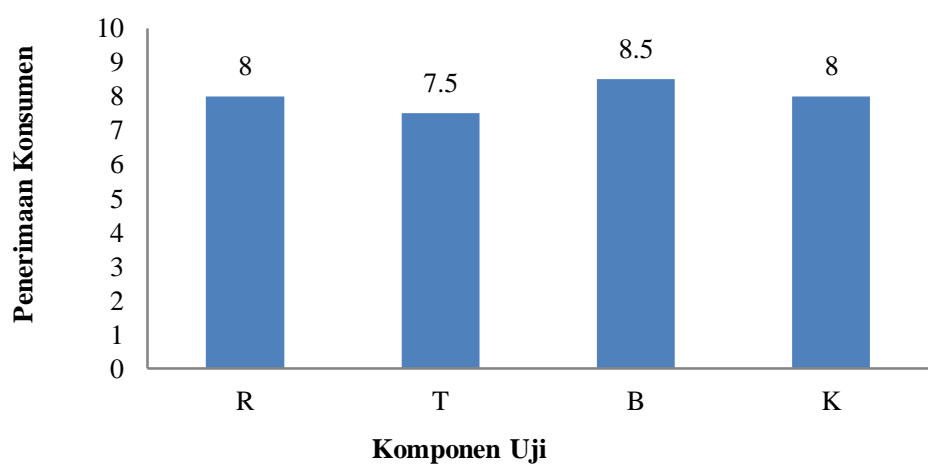

Gambar 4. Penerimaan Konsumen Terhadap Kaki Naga Ikan. Ket.: $\mathrm{R}=$ rasa, $\mathrm{T}=$ Tekstur, $\mathrm{B}=\mathrm{Bau}, \mathrm{K}=$ Kenampakan.

Data di atas menunjukkan bahwa penerimaan konsumen terhadap rasa dari kaki naga ikan adalah rata-rata sangat disukai dengan skor nilai adalah 8 . Terhadap tekstur rata-rata antara suka dan sangat suka dengan skor nilai adalah 7,5. Terhadap bau rata-rata antara sangat suka dan amat sangat suka dengan skor nilai adalah 8,5. Sedangkan terhadap kenampakan rata-rata penerimaan konsumen adalah sangat suka dengan skor nilai adalah 8. Hayati, dkk. (2012), menyatakan bahwa rasa, tekstur, bau dan kenampakan merupakan kumpulan kata untuk mendeskripsikan karakteristik sensori pada suatu produk pangan.

\subsection{Nugget Ikan.}

Hasil uji hedonik tentang penerimaan konsumen terhadap rasa tekstur, bau dan kenampakan pada produk nugget ikan dapat dilihat pada Gambar 5.

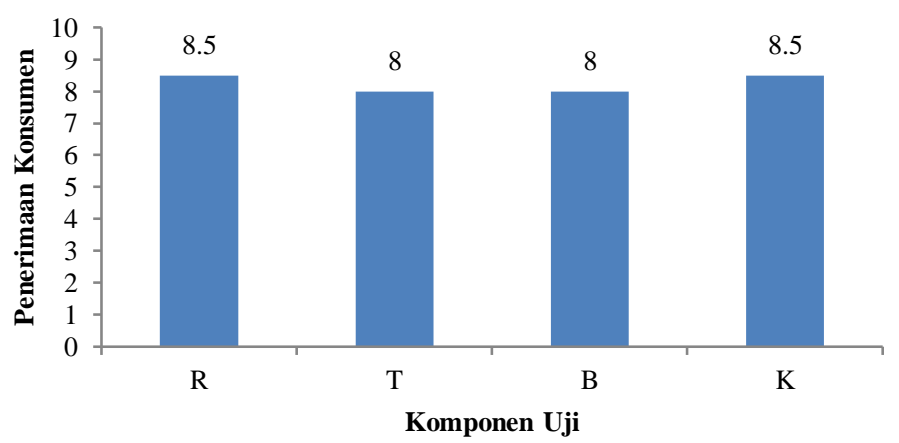

Gambar 5. Penerimaan Konsumen Terhadap Nugget Ikan Ket.: $\mathrm{R}=$ rasa, $\mathrm{T}=$ Tekstur, $\mathrm{B}=\mathrm{Bau}, \mathrm{K}=$ Kenampakan.

Data di atas menunjukkan bahwa penerimaan konsumen terhadap rasa dari nugget ikan adalah rata-rata diantara sangat disukai dan amat sangat disukai dengan skor nilai adalah 8,5. Terhadap tekstur rata-rata sangat suka dengan skor nilai adalah 8. Terhadap bau rata-rata sangat suka dengan skor nilai adalah 8,0. Sedangkan terhadap kenampakan rata-rata penerimaan konsumen adalah antara sangat suka dan amat sangat suka dengan skor nilai adalah 8,5. Menurut Meilgard et al., (2006) atribut yang paling penting pada suatu produk yang dipertimbangkan oleh 
konsumen untuk memilih sebuah produk adalah kenampakan, dibandingkan dengan atribut sensori lainnya. Kenampakan dari suatu produk yang baik cenderung akan dianggap memiliki rasa yang enak dan memiliki kualitas yang tinggi. Karakteristik kenampakan merupakan gambaran umum tentang produk yang meliputi warna, ukuran, bentuk, tekstur permukaan, tingkat kemurnian dan karbonasi produk.

\subsection{Ilobulo Ikan.}

Hasil uji hedonik tentang penerimaan konsumen terhadap rasa tekstur, bau dan kenampakan pada produk Ilobulo ikan dapat dilihat pada Gambar 6.

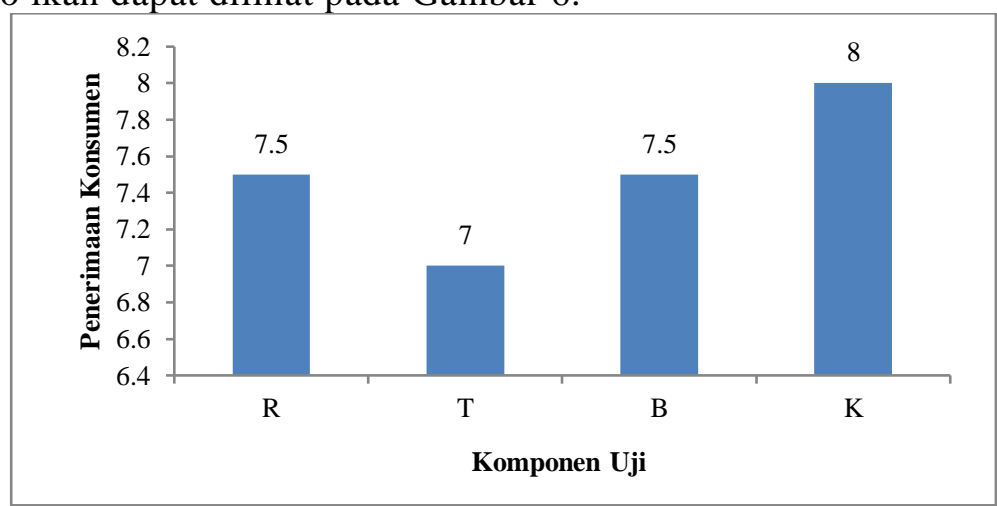

Gambar 6. Penerimaan Konsumen Terhadap Ilobulo Ikan. Ket.: $\mathrm{R}=$ rasa, $\mathrm{T}=$ Tekstur, $\mathrm{B}=\mathrm{Bau}, \mathrm{K}=$ Kenampakan.

Data di atas menunjukkan bahwa penerimaan konsumen terhadap rasa dari Ilobulo ikan adalah rata-rata diantara sangat disukai dan disukai dengan skor nilai adalah 7,5. Terhadap tekstur rata-rata suka dengan skor nilai adalah 7 . Terhadap bau rata-rata sangat suka dan disukai dengan skor nilai adalah 7,5. Sedangkan terhadap kenampakan rata-rata penerimaan konsumen adalah sangat disukai dengan skor nilai adalah 8. Bau makanan merupakan senyawa yang mudah menguap yang dihirup oleh rongga hidung ketika manusia bernapas, juga bisa masuk dari belakang tenggorokan selama seseorang sedang makan (Kemp et al., 2009). Menurut Antara dan Wartini (2014), senyawa yang menyebabkan bau berperan penting dalam memproduksi penyedap, untuk meningkatkan rasa dan untuk meningkatkan daya tarik produk tersebut. Tekstur adalah perpaduan sifat fisik yang terdiri dari ukuran, bentuk, jumlah dan unsur-unsur pembentuk bahan yang dapat dirasakan oleh beberapa indera seperti peraba, perasa, indera mulut dan mata (Midayanto dan Yuwono, 2014). Cita rasa merupakan salah satu faktor yang menentukan kualitas makanan, karena dapat menimbulkan sensasi rasa. Selain itu cita rasa dapat membangkitkan rasa lewat aroma yang dihasilkan.

\section{KESIMPULAN}

- Pelaksanaan pengabdian seperti diversifikasi produk olahan ikan sangat ditunggu-tunggu oleh ibu-ibu PKK, karena melalui pengabdian tersebut ibu-ibu PKK mendapatkan ilmu untuk menyediakan makanan yang B2SA (Beragam Bergizi Seimbang dan Aman) karena banyak makanan yang tersedia di pasaran yang mereka anggap kurang aman.

- Dalam mengisi kejenuhan di masa adaptasi kebiasaan baru, ibu-ibu PKK memperoleh bisnis kuliner yang baru, yang mereka boleh tawarkan ke pasar untuk mengembangkan bisnis kuliner yang mereka jalani selama ini.

- Produk yang ditawarkan yaitu: Kaki naga ikan, nugget ikan dan ilobulo ikan, dari hasil uji hedonik ternyata dapat diterima oleh ibu-ibu PKK dan keluarga Karena penerimaan mereka adalah dari suka sampai sangat suka.

\section{DAFTAR PUSTAKA}

Antara, N. dan Wartini, M. 2014. Aroma and Flavor Compounds. Tropical Plant Curriculum Project. Udayana University.

Diana, F.M. (2013). Omega 3 dan Kecerdasan Anak. Jurnal Kesehatan Masyarakat. Vol.7, No. 2. 
Elizabeth, R. 2011. Strategi Pencapaian Diversifikasi dan Kemandirian Pangan: Antara Harapan dan Kenyataan. J. Iptek Tanaman Pangan. Vol. 6. No. 2.

Hayati, R., Marliah, A. dan Rosita, F. 2012. Sifat kimia dan Evaluasi Sensori Bubuk Kopi Arabika. Jurnal Florstek, 6675.

Innis, S. M. 2000. The Role of Dietary n-6 asnd n-3 Fatty Acids In The Developing Brain. Developmental Neuroscience. Vol. 22. No. 5-6.

Kadam, S.U. and Prabhasankar, P. 2010. Marine Food as Functional Ingredients in Bakery and Pasta Products. Food Research International 43. Pp:1975-1980.

Kemp SE., Hollowood T. and Hort J. 2009. Sensory Evaluation: A Practical Handbook. Wiley Blackwell, United Kingdom.

Larsen, R, Eilersten, K.E., and Elvevoll, E.O. 2011. Health Benefits of Marine Foods and Ingredients. Biotechnology Advaces 29. pp: 508 G518.

Meilgard, M., Civille, GV. and Carr, BT. 2006. Sensory Evaluation Techniques Fourth Edition. CRC Press. USA.

Midayanto, D. and Yuwono, S. 2014. Penentuan Atribut Mutu Tekstur Tahu Untuk Direkomendasikan Sebagai Syarat Tambahan dalam Standar Nasional Indonesia. Jurnal Pangan dan Agroindustri. 2: 4, 259-267.

Susanto E. dan Fahmi A. S. (2012). Senyawa Fungsional dari Ikan: Aplikasinya dalam Pangan. Jurnal Aplikasi Teknologi Pangan, 1(4), 95-102.

Soccol, M.C.H. and Oetterer, M. 2003. Seafood as Functional Foods. Brazilian Archives of Biology and Technology. An International Journal.46:443G454.

Wahyudi, M. 2006. Proses Pembuatan dan Analisis Mutu Yogurt. Buletin Teknik Pertanian. 11 (1)):12Z16.

Wahyudi, A. dan S. Samsundari. 2008. Bugar dengan Susu Fermentasi. Universitas Muhammadiyah Malang Press, Malang.

WHO World Health Organization. 2013. Diabetes. http://www.who.int/mediacentre/factsheets/fs312/en.html.

Widyastuti, 2007. Radio farmakologi Berbasis Anti Bodi. J. Radioisotop dan Radiofarmaka. Oktober. Vol.10.

Virtanen T., Pihianto, A., Makinem, S and H. Korhonen. 2007. Development of Antioxidant Activity in Milk Whey During Fermentation with Lactic Acid Bacteria. Journal Applied Microbiology. 102(1):106-15. 